\title{
Financial Intermediation Development and Economic Growth Nexus in Sri Lanka
}

\author{
M C Dilhan De Silva
}

\begin{abstract}
This paper investigates the causal relationship between financial development and economic growth in Sri Lanka for the period 1965 to 2013 using a trivariate vector autoregressive (VAR) framework that includes investment as an additional variable. This study utilized Per Capita Gross Domestic Product (GDP) and investment (as a measurement of indirect effect) as proxies for economic growth. Money supply, bank deposits and domestic credit to the private sector, each as a percentage of GDP were used as proxies for financial development. Data analysis involved Granger causality tests using the Johansen cointegration test and Vector Error Correction Model (VECM). Results show strong long-run Granger causality of financial development to economic growth in Sri Lanka. Furthermore, results suggest evidence of bi-directional short-run causalities between bank deposits and economic growth, and unidirectional causality from money supply to economic growth. The major implication of research findings is that enhancing financial sector development policies will improve productivity and drive long run economic growth in Sri Lanka.
\end{abstract}

Key Words: Causality, Cointegration, Development, Financial Intermediation, GDP Growth, VECM

JEL Classification: C320, O110, 043 


\section{Introduction}

The causality behavior between financial development and economic growth has been a controversial issue. The debate focused on whether the economic growth leads financial development or vice versa. The aim of this study is to determine the causality behavior between the development of financial intermediaries and the economic growth in Sri Lanka, for the past five decades. This study employs Granger causality tests under the environment of cointegration and the Vector Error Correction Model (VECM).

In an economy, financial intermediaries perform an essential function of transferring surplus financial resources to the deficit. Finance plays a key role in driving innovation and entrepreneurship, which are the main forces of economic growth. Joseph Schumpeter (1911) emphasised this nexus of financial development and economic growth. According to Schumpeter, financial sector development mobilizes savings and allocates funds efficiently by alleviating frictions due to asymmetric information and by enhancing investors' risk taking capacity (as cited in Shin 2013). Later, the Schumpeterian theory was recast analytically by Goldsmith (1969) and Shaw (1973), indicating that the financial sector plays a major role in economic growth by making available an efficient credit line, better risk management processes, and minimizing adverse selection and moral hazards by reducing information asymmetries. In contrast to the view that the finance sector drives economic development, Robinson (1952) and Kuznet (1955) argued that growth of real economy leads while finance follows. Further, Levine (1997) also denotes that finance plays a minor role in economic development as financial output improves as a reaction to the high demand of economic growth.

Based on this causality debate, Wolde-Rufael (2009) make two hypotheses: 1. Supply-leading hypothesis (finance drives economic growth) and 2. Demand-following hypothesis (economic growth influences financial sector development). However, extensive empirical evidence show no consensus on the direction of causality since most economies show a bi-directional causality between economic growth and financial development (Abu-Bader \& Abu-Qarn 2007; Greenwood \& Smith 1997). Later, Abubaker and Gani (2013) added two new hypotheses; 1. Reciprocal hypothesis and 2. Neutral hypothesis.

The pattern of the causality between economic and financial development may vary among countries. Thus, variable factors such as economic structures, government controls (e.g., interest rate ceilings, mandatory or direct credit programs), strength of corporate governance, institutional structures and reserve requirement may have differing impacts on economic growth and financial development for different countries (Wolde-Rufael 2009). Hence, identification of the causality between finance-growth of a country is important to produce macro-economic and financial decisions, whether causality is uni-directional or bi-directional.

In the Sri Lankan banking sector, which represents 57.6\% of total assets of the financial sector, risk and branch distribution are well managed (CBSL 2013). But, popular financial 
development indicators have exhibited slow growth over the last two decades, which creates questions about the contribution of financial intermediaries to economic growth of the country. Therefore, the objective of this study is to empirically investigate the nexus between financial development and economic growth.

In the Sri Lankan case, Perera and Paudel (2009) found reciprocal causality of economic growth and financial development. Amarathunga (2010) found that demand followed causality in the long run.

Singh (2008) and Abu-Bader and Abu-Qarn (2007) explain that a larger time series is more important rather than a larger number of observations in cross estimations, to identify the long-run cointegrations. This study uses a Sri Lankan time series data, set for the period of 1965 to 2013. Research methods involved utilization of the Granger causality test, Johansen cointegration test and VECM, all of which are popular methods to identify long-run and shortrun relationships of financial development and economic growth.

This paper explores the nexus between financial development and economic growth with specific reference to the economy of Sri Lanka. In the following section, the financial development and economic growth of Sri Lanka is described. Section 3 examines the theoretical underpinnings of financial development and economic growth, while Section 4 presents the econometric methods utilized in this study. Empirical results of this study are presented in Section 5, followed by presentation of the empirical literature and discussion of this study's results in Section 6. Finally, Section 7 discuss the policy implications and concludes the topic of the nexus of financial development and economic growth in Sri Lanka.

\section{A Review of Sri Lankan's Financial Development and Economic Growth}

In order to examine the nexus between financial development and economic growth in Sri Lanka, it is first important to understand the key historical milestones, particularly of the past five decades, that have impacted Sri Lanka's economy. From independence in 1948 and until 1965, Sri Lanka maintained an inward-looking development approach. From 1966 to 1970, Sri Lanka changed policies due to partial liberalization. 1970 to 1977 was the second phase of inward-looking policies, characterized by import substitution and increased government intervention including the financial sector. Such economic policies resulted in domestic pressure, which led to the first civil war in the country after independence. However, implementation of the inward-looking policy of this time was hampered significantly, mainly due to the world oil crisis in 1973, which was followed by a food and fertilizer crisis. Between 1965 and 1977 the country maintained 4\% annual growth with noticeable fluctuations (Figure 1). From 1977, Sri Lanka began an outward-oriented development policy. Considering trade as the engine of economic growth, the government made sweeping initial policy reforms in several sectors, including the financial sector (World Bank 2004). 
Figure 1: Annual GDP growth (\%) of Sri Lanka (1965-2013)

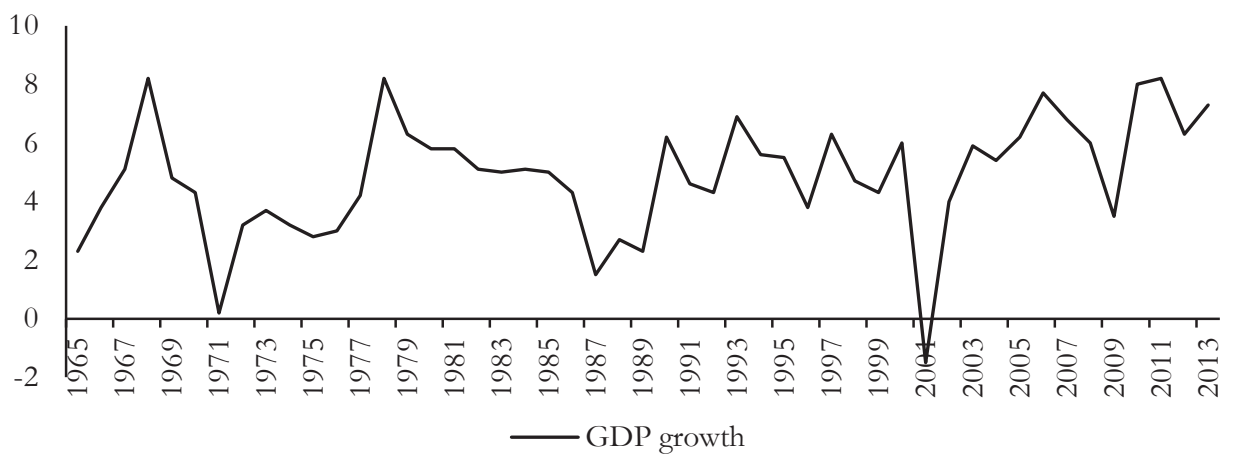

Source: Central Bank of Sri Lanka (2013)

After 1977, Sri Lankan financial reforms consisted of deregulating of interest rates, relaxing credit ceilings, reducing state bank authority by minimization of private bank entry constraints, introducing offshore banking units and systems for efficient payment and settlements. Furthermore, the Sri Lankan government introduced monetary authority reforms, involving the liberalization of the exchange rate and reduction in reserve requirements. Also, several reforms were implemented with regard to legal processes. After financial liberalization, market forces stimulated the arrival of foreign banks with developed financial products. This banking environment created an efficient fund channeling system with attractive and competitive products for savers and borrowers with less information cost (CBSL 1978). Figure 2 shows these changes in financial development indicators and Figure 1 shows a higher spike of economic growth after 1977.

During the 1977 to 2013 period, several noticeable economic downturns affected the economy. The Civil war began in 1983 due to the activities of a terrorist organization (LTTE ${ }^{1}$ ) and ended in 2009. In addition, the country faced similar violent political clashes during the 1987 to 1991 period. Parallel to these events, Figure 1 and 2 show noticeable downturns of growth and the decline of total domestic credit in 1983, respectively. Further, Figure 2 shows a significant decline of both private domestic credit and total domestic credit in the 1987 to 1991 period. In the year 2001, the country recorded negative growth for the first time following independence. The economic slowdown was mainly due to lower performances in manufacturing and trade, which had been adversely affected by the global recession, the impact of extended drought on agriculture and hydropower generation, and a drop in tourism and port aviation services due to terrorist activities (CBSL 2001).

${ }^{1}$ Liberation Tigers of Tamil Elam 
Figure 2: Indicators of Sri Lanka's financial sector Development (as \% of GDP)

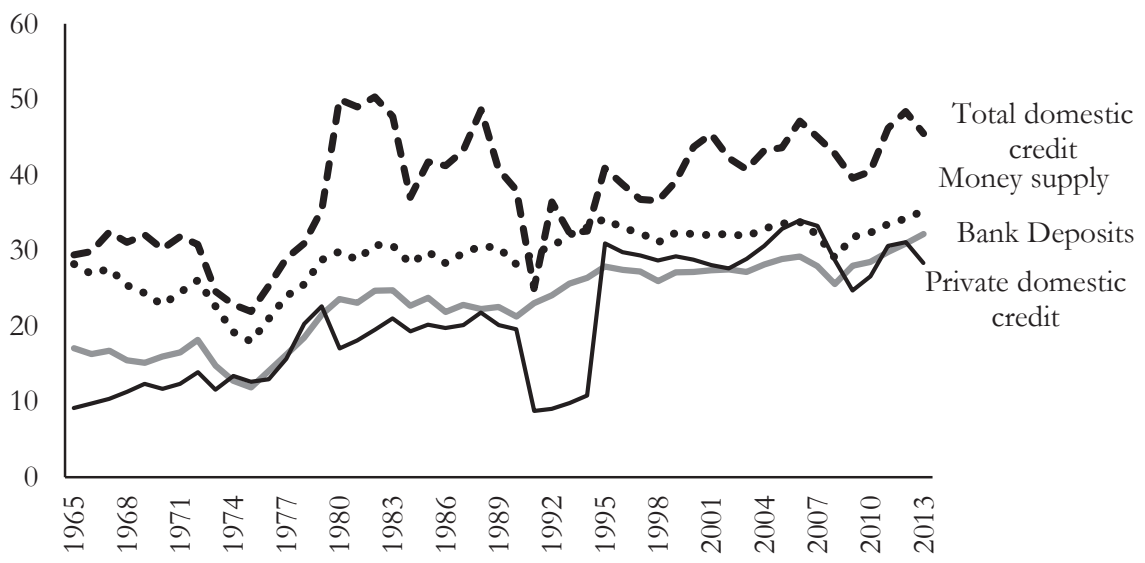

Sources: Central Bank of Sri Lanka (2013), World Development Indicators (2013)

After financial reforms, the banking sector, as the pioneer of financial intermediation in Sri Lanka dramatically developed during the last 3.5 decades, from 1977. In 2013, the financial sector showed 8.7 percent contribution to the GDP, compared to only 1.5 percent in 1977 . The major part of the financial sector is license banks, which make up 57.6 percent of total assets of the financial sector. When the assets of the Central Bank are included, the total assets of the Sri Lankan financial sector increase to 69.7 percent. While in 1977, the country had 22 banks, by 2013 the number of licensed banks had increased to 33, including 12 foreign bank branches. In line with this development in the banking sector, the number of bank branches in 2013 was 6487, compared to 768 in 1977. Further, banking density ${ }^{2}$ in the country had increased to 16.8. These figures show the facilitation of present financial intermediaries for economic growth goals (CBSL 1977; CBSL 2013).

Presently, the Sri Lankan banking sector maintains risk management procedures in an integrated manner, in a well regulated environment. Sri Lanka is one of the pioneers in the region for adaption of Basel requirements, i.e. international regulatory frameworks for banks. At the end of 2013, the Central Bank issued Basel II- Pillar 2 directions on capital requirement for risks not covered in Basel II - Pillar I. Presently, the Sri Lankan banking sector complies with the Basel III capital requirement. Further, financial intermediaries are adapting well to the recently introduced International Accounting Standards (IAS) (CBSL 2013).

\footnotetext{
${ }^{2}$ Number of bank branches for 100,000 persons.
} 
Sri Lanka's banking structure has developed systematically. However, financial development indicators show stagnating behavior or marginal growth during the last two decades. Figure 2 displays slow movements of the key indicators, money supply, banking deposits and credit granted to the domestic private sector, which are represented as a percentage of GDP. Despite low interest rates maintained by the banks, credit to the private sector is in a state of stagnation. Recently, the Central Bank of Sri Lanka introduced a Standing Deposit Facility (SDF) to absorb excess liquidity from the banking sector (CBSL 2014).

Table 1: Financial development in Sri Lanka (comparison with other regions): 2012

\begin{tabular}{lcccc}
\hline \hline & $\begin{array}{l}\text { Total Domestic } \\
\text { credit (by } \\
\text { financial sector) } \\
\text { (\% of GDP) }\end{array}$ & $\begin{array}{l}\text { Domestic } \\
\text { credit to } \\
\text { private sector } \\
\text { by banks } \\
\text { (\% of GDP) }\end{array}$ & $\begin{array}{l}\text { Money and } \\
\text { quasi money } \\
(\mathbf{M} 2) \\
(\% \text { of GDP) }\end{array}$ & $\begin{array}{l}\text { Interest rate } \\
\text { spread } \\
\text { (lending rate } \\
\text { minus } \\
\text { deposit } \\
\text { rate, \%) }\end{array}$ \\
\hline Sri Lanka & & 31.09 & 38.66 & 4.62 \\
South Asia & 48.43 & 46.68 & 70.49 & 5.54 \\
East Asia \& Pacific & 206.06 & 118.28 & 183.85 & 5.00 \\
Middle East \& & 35.74 & 34.49 & 53.85 & 3.71 \\
North Africa & & 31.02 & 40.27 & 8.57 \\
Sub-Saharan Africa & 65.59 & 44.12 & 55.83 & 7.00 \\
Latin America \& & 73.62 & & & \\
Caribbean & & 88.32 & 125.06 & 5.95 \\
World & 167.11 & & & \\
\hline
\end{tabular}

Source: World Bank, World Development Indicators (2012)

World developments indicators (WDI) (2012) define the proxies of financial development stated in Table 1 as follows; Domestic credit provided by the financial sector refers to all gross credit grants to various sectors (except credit to the government). Financial sector is defined as monetary authority, banks holding deposits, insurance corporations, pension funds, foreign exchange companies and other finance companies. Domestic credit to private sector by banks denotes the allocation of financial resources by deposit taking corporations (except central banks) to the private sector. These credit schemes may refer to loans, buying of non-equity securities and trade finances. The definition of the Money and quasi money (M2) as per WDI (2012) is "the sum of currency outside banks, demand deposits other than those of the central government, and the time, savings, and foreign currency deposits of resident sectors other than the central government". Interest rate spread is the difference between the interest rate charge for bank loans to the private sector and the interest rate paid by the banks for deposits.

Table 1 shows that Sri Lanka lags far behind in most of the financial development measures in comparison with several regions of the world. While the interest spread remains low among 
other regions except the Middle East and North Africa, credit to the private sector is low in the country.

\section{Finance Development and Economic Growth -Theoretical Underpinning}

This section develops the theoretical background for understanding how financial intermediary development impacts productivity and influences economic growth. In this section the causal relationship between financial development and economic growth is also explored.

Meon \& Weill (2010) state that factor productivity is the main driver of economic growth, rather than factor accumulation. Consequently, productivity has become the determining factor for the country's income. Levine (2005) shows that financial development plays a major instrumental role in economic growth, by increasing productivity. A wide range of literature explains, with different arguments, how the financial intermediary can improve productivity. Odenarian and Udeaja (2010) and Meon and Weill (2010) clarify four major functions of the intermediation process:

The first function of the financial system is to provide information and reduce investment appraisal cost. Rajan and Zingals (1998) specifically highlighted that the reduction of information asymmetries minimizes adverse selection and moral hazard concerns of investors. Thus, capital allocation is efficient and less costly, leading to high productivity.

The financial intermediary's second function is monitoring capitalized firms. Financial systems use corporate governance practices to control borrowers (firms) and manage financial intermediation firms. Meon and Weill (2010) state that improved corporate governance practices and a controlled follow-up environment reduces the moral hazard problem by creating a framework that ensures managers in banks and owners in firms utilize invested funds appropriately. The overall result of improved governance and follow-up practices is increased productivity, which leads to economic growth.

The third function of the financial intermediary is efficient savings mobilization, with reduced transaction cost and high transparency for savers. Hence, intermediation improves the allocation of excess funds towards investment.

The last function is to provide a platform to exchange goods and services in the economy. Financial intermediaries facilitate the function with a media of exchange and this specialization improves economic productivity and drives economic growth. Meon and Weill (2010) present the counterarguments of financial development, as it will tend to increase the likelihood of a financial crisis. These authors state that financial liberalization and incentives for banks to increase their lending may cause credit bubbles. 
Aggregate production function, describes how real GDP is driven by total available inputs and as inputs increase, so do outputs. Similarly, in a financial system, conversion of inputs, namely savings and investments, are directly related to maximum output. The development of financial intermediary functions contributes to this process through the channels of technological change or capital accumulation (Williamson 2011).

Williamson (2011) used the Solow growth model to explain how a rise in the savings rate(s) increases capital (capital per worker) (k) and output per worker (y) with upturn of steady state level in a country. Figure 3 shows that when savings rate increases from $s_{1}$ to $s_{2}$, capital accumulation increases from $\mathrm{k}_{1}$ to $\mathrm{k}_{2}$. Hence, in the steady level, output will grow from $\mathrm{y}_{1}$ to y2 (Figure 3).

Figure 3: Change in savings rate in the Solow growth model

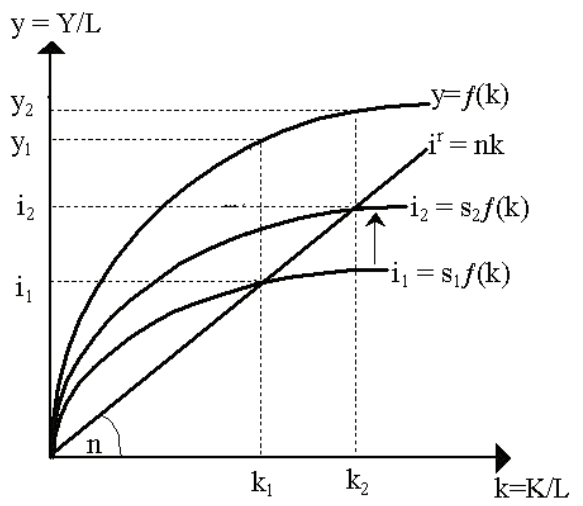

Source: Macroeconomics, Williamson (2011)

Further, the Solow growth model explains the effect of factor productivity ( $\mathrm{z}$ ) to the output per worker, when $y=z f(k)$. According to Figure 4, change in factor productivity from $z_{1}$ to $z_{2}$ causes an increase in capital accumulation from $\mathrm{k}_{1}$ to $\mathrm{k}_{2}$ and GDP per worker from $\mathrm{y}_{1}$ to $\mathrm{y}_{2}$ (Figure 4). Thus, the model explains the increase in factor productivity due to technological change (may be due to financial intermediation effect) of an economy driving economic growth (Williamson 2011). 
Figure 4: Change in factor productivity in the Solow growth model

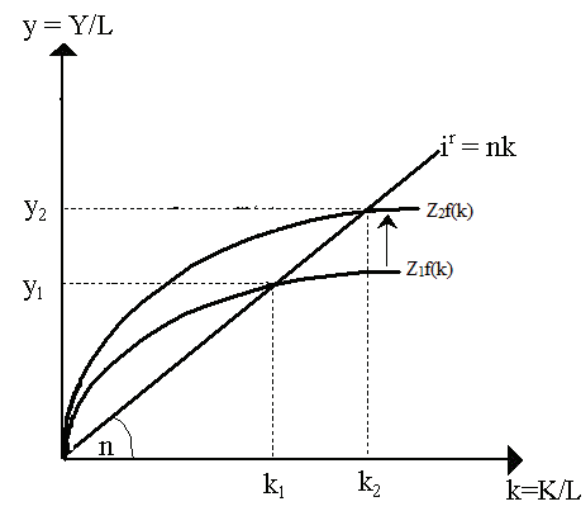

Source: Macroeconomics, Williamson (2011)

There is a positive correlation between financial development and economic growth (Shin 2013). According to Shin's (2013) theoretical analysis, the requirement of new capital allocation of a firm due to productivity changes occurs over time. But, the level of financial frictions is a controlling factor of capital generation. Thus, financial friction may cause not only capital misallocation, but may also waste entrepreneurial talents by delaying the firms' entry decisions. Further, financial friction distorts firms operating in both manufacturing and services sectors. Hence, Shin (2013) concluded that the development of the financial sector alleviates financial friction, promotes productivity and results in long run economic growth.

Literature on the finance-economic relationship covers the early $19^{\text {th }}$ century to present. Wolde-Rufael (2009), Abubaker and Gani (2013) and many other researchers discussed four key hypotheses for the link or causality between the development of financial intermediation and growth of the economy; supply leading hypothesis, demand following hypothesis, reciprocal hypothesis and neutrality hypothesis (Figure 5). 
Figure 5: Four key hypotheses for the causality between the financial development and economic growth

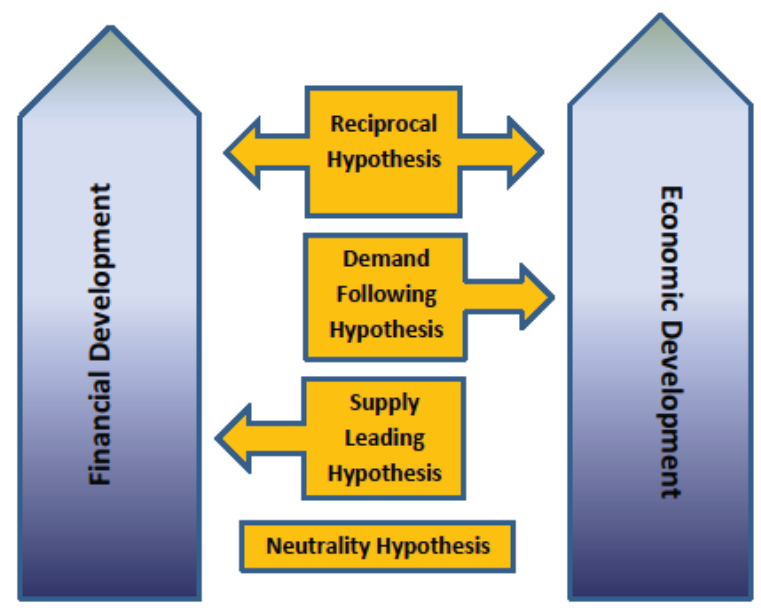

Schumpeter (1911) explained that banks in the financial market perform a major role in the process of real economic growth. This author observed that banks play a role in efficient fund mobilizing and credit channeling to entrepreneurs who invest in new technology. Schumpeter (1911) concluded that financial development causes growth of the economy, known as the supply leading bypothesis. While Schumpeter was the pioneer of this assumption, Goldsmith (1969) and Shaw (1973) later tested this hypothesis analytically. These authors show that a blocked financial situation, such as higher reserve requirement, implementing limits on interest rates and compulsory or regulated credit policies result in economic growth decline. In response to this situation, financial liberalization policies increase financial intermediary activities, resulting in economic growth (Abubaker \& Gani 2013). Further, Rajan and Zingals (1998) similarly concluded that the supply of financial products is a lubricant to economic growth.

In contrast to the above hypothesis, Robinson (1952) and Kuznets (1955) emphasizes that finance is a byproduct of economic growth, where growth leads to financial development, and this is the demand following hypothesis (Abubaker \& Gani 2013; Wolde-Rufael 2009; Amarathunga 2010). Further, Wolde-Rufael (2009) explains that new financial products arise in the market as a response to growth. Hence, developing countries usually lack the demand for new complex financial products compared to developed countries.

Further, research by Abu-Bader and Abu-Qarn (2007), Wolde-Rufael (2009) and Singh (2008) show a causality between financial development and economic growth as bi-directional, which is termed the reciprocal hypothesis. Abubaker and Gani (2013) point out that developing countries' 
financial development become supply leading, whereas, in developed countries growth leads and financial development follows. But some empirical analyses (e.g., Abu-Bader and AbuQarn 2007) prove that developing countries display the demand following hypothesis. In some circumstances, there is no causality between finance development and economic growth, and this is called the neutrality hypothesis. Blum et al (2002) highlight that if the economy consists of perfect information and the transaction cost is zero (neo classical assumptions), indifference exists between the financial sector and internal or external fund sources. However, Abubaker and Gani (2013) explain that these assumptions are not realistic because the neutrality hypothesis cannot exist in an economy.

Abubaker and Gani (2013) state that economic comparisons of different countries, conducted with either panel data or cross sectional methods, depend on assumptions of homogeneity across compared economies. Furthermore, a comprehensive and comparative study requires consideration of specific economic conditions, financial structures, policies and institutions of each country. As such, time series analyses are more suitable for economic studies of individual countries.

\section{Methodology}

This econometric study measured financial development and economic growth in Sri Lanka over approximately five decades. This section describes methods used to measure economic growth and financial development, and presents the econometric methods used to determine finance-economic causality.

\subsection{Measurement and Data Sources}

This study utilized annual, financial data for the period of 1965 to 2013. Data was extracted from World Development Indicators online (2013) and various annual reports of the Central Bank of Sri Lanka.

According to the empirical literature, real GDP per capita $(G)$ is used as the measurement of economic growth of a country. In addition to G, country investment (INV) is considered an economic variable to facilitate the measure of robust correlation of financial development and economic growth. Since financial development cannot be captured through a single proxy, three measures are used in this study to improve the robustness of the findings. Each measurement is defined in Section 2.

(1) Money Supply (M2) to GDP (M2G) ratio measures financial depth. Odenarian and Udeaja (2010) describe that M2G measures the monetization level and financial depth of the economy.

(2) Bank Deposits to GDP (BD) ratio is determined by M2 minus currency to GDP. AbuBader and Abu-Qarn (2007) and Odenarian and Udeaja (2010) show that BD determines the 
capability of fund allocations between savers and borrowers, which indicate the degree of financial intermediation by the banking sector.

(3) Private Domestic Credit to GDP (PDC) ratio determines the opportunities for new investments. Wolde-Rufael (2009) and Abu-Bader and Abu-Qarn (2007) stated that PDC is an effective way to measure quantity and efficiency of fund allocations to new projects.

In the model FD (=M2G or BD or PDC), G and INV date series are converted to the logarithmic form ${ }^{3}$ to reach stationary variance.

\subsection{The Econometric Methodology}

Granger causality in economics is the ability to forecast the future values of one variable's $\left(v_{1}\right)$ time series, by using another variable's ( $\left.\mathrm{v}_{2}\right)$ time series. Granger causality tests are using to determine the statistical hypothesis of whether a time series of $\mathrm{v}_{1}$ helps to predict $\mathrm{v}_{2}$ at some stage in the future (Enders 2009).

Data analysis of the study occurred according to the following steps: unit root test, Granger causality tests under the environment of cointegration test and VECM.

Unit root test: The first step of analysis was to test the unit root and stationarity to determine stationary status (i.e., $\mathrm{I}(0)$ or $\mathrm{I}(1)$ ) of the variables. Determination of the order of integration is important to cointegration analysis. This study used Augmented Dickey Fuller (ADF) and Phillips-Perron (PP) unit root tests according to the following equation.

$$
\Delta y_{t}=c_{0}+\gamma y_{t-1}+c_{1} t+\sum_{t=1}^{k} \Phi_{i} \Delta y_{t-1}+\varepsilon_{t}
$$

In the equation, $c_{0}$ is intercept, $t$ represent linear time trend, $k$ is the number of lagged first differences, $y_{t}$ denotes time series variable, $\Delta$ shows the operator for first difference, and $\varepsilon_{t}$ is the error term (Odenarian and Udeaja 2010). First, unit root tests were conducted on the variables are in level. If a variable did not reach stationary, then more differencing was done until stationary was reached. The null hypothesis of unit root existence was rejected if $\gamma$ was significantly different from zero. Whenever the test confirmed the presence of a unit root in some of the data series, the questions arose regarding the existence of long-run relationships between variables, which are termed cointegration.

${ }^{3} \log (\mathrm{G})=\ln \mathrm{G}, \log (\mathrm{INV})=\ln I N V, \log (\mathrm{M} 2 \mathrm{G})=\ln M 2 \mathrm{G}, \log (\mathrm{BD})=\ln \mathrm{BD}, \log (\mathrm{PDC})=\ln \mathrm{PDC}$ 
The study used Akaike Information Criterion (AIC) and Schwarz Information Criterion (SC) as lag order selection criteria. Lag length determination is required for the cointegration and VECM (Abu-Bader \& Abu-Qarn 2007).

According to Engle and Granger (1987), determination of causality through VECM representation occurs as a two-step procedure, assuming that variable $\left(y_{t}\right)$ is $\mathrm{I}(1)$. The first step is to test whether the data series is cointegrated through cointegration regression. Second, after rejecting the null hypothesis of the first regression, run the VECM.

Cointegration test: The next step is to measure cointegration between variables. The method determines cointegration as a system of equation in a single step, established on the $p$ dimensional VAR, where $\mathrm{p}$ is the lag order (Johansen 1988).

$$
\Delta y_{t}=\pi y_{t-1}+\sum_{i=1}^{p-1} \tau_{i} \Delta y_{t}+\delta X_{t}+\epsilon_{t}
$$

In the equation; $\Delta$ is a difference operator, $y_{t}$ is a nx1 vector of non-stationary variables, $\pi$ and $\tau$ are coefficients of nxn matrices, $X_{t}$ denotes other deterministic variables like trend, dummies and constant and $\epsilon_{t}$ is the normally distributed error term. $\pi$ matrix gives information about the cointegration vector (Bojanic 2012; Abu-Bader \& Abu-Qarn 2007).

For determination of the rank (r) of $\pi$, Johansen (1988) and Johansen and Juselius (1990) proposed two tests: Maximum Eigen value test and Trace test. For both tests, the null hypothesis is no cointegration among variables and the alternative hypothesis is the existence of $r \geq 1$ cointegrating vector.

Determination of cointegration is via testing the rank ( $\mathrm{r}$ ) of the coefficient matrix $\pi$. If the rank is $0<\mathrm{r}<\mathrm{n}$, then $\pi$ can be decomposed into $\pi=a \beta$, where $a$ and $\beta$ represent (nxr) matrices. $\beta$ represents the level of significance for the cointegrating relationship among variables. $a$ is the adjustment coefficient, which is the speed of error correction (Acaravci et al 2007; Bojanic 2011).

Vector error correction model (VECM): In the model, $y_{t}$ is a $3 \times 1$ vector, which is $\mathrm{I}(1)$. Variables in the matrix $\left(y_{t}\right)$ include $y_{1}=\ln G, y_{2}=\ln (\mathrm{FD}), y_{3}=\ln I N V$. Abu-Bader and AbuQarn (2007) developed a trivariate Vector Auto Regression (VAR) model consisting of three equations, with two economic growth variables consisting of $y_{1}$ and $y_{3}$ together and three different $y_{2}$ s representing three financial development indicators. This paper uses this VECM approach to determine the nexus between financial development and economic growth. 


$$
\begin{gathered}
\Delta y_{1 t}=\mu_{1}+\sum_{h=1}^{r} \alpha_{1, h} E C T_{h, t-1}+\sum_{k=1}^{p-1} \beta_{11 . k} \Delta y_{1, t-k}+\sum_{k=1}^{p-1} \beta_{12 . k} \Delta y_{2, t-k}+ \\
\sum_{k=1}^{p-1} \beta_{13 . k} \Delta y_{3, t-k}+\varepsilon_{1 t}(3) \\
\Delta y_{2 t}=\mu_{2}+\sum_{h=1}^{r} \alpha_{2, h} E C T_{h, t-1}+\sum_{k=1}^{p-1} \beta_{21 . k} \Delta y_{1, t-k}+\sum_{k=1}^{p-1} \beta_{22 . k} \Delta y_{2, t-k}+ \\
\sum_{k=1}^{p-1} \beta_{23 . k} \Delta y_{3, t-k}+\varepsilon_{2 t}(4) \\
\Delta y_{3 t}=\mu_{3}+\sum_{h=1}^{r} \alpha_{3, h} E C T_{h, t-1}+\sum_{k=1}^{p-1} \beta_{31 . k} \Delta y_{1, t-k}+\sum_{k=1}^{p-1} \beta_{32 . k} \Delta y_{2, t-k}+ \\
\sum_{k=1}^{p-1} \beta_{33 . k} \Delta y_{3, t-k}+\varepsilon_{3 t}(5)
\end{gathered}
$$

The error correction term (ECT) leads the variables of the system to restore back to equilibrium. After estimation, ECT should be negative. In the equation $\mathrm{ECT}_{b, t-1}$ defines the $b$ th ECT. The bth ECT explains the residuals of $h$ th cointegration equation, which is one lag period. $\beta_{i j . k}$ is explained as $k$ th lagged value of $j$ th variable for the current value of $i$ th variable ( $i$ and $\left.j=y_{1}, y_{2}, y_{3}\right)$.

The VECM indicates two features in the system as follows:

(i) Identification of causality direction between variables.

(ii) Differentiation of causality as short-run dynamics and long-run equilibrium adjustment (Enders 2009).

Existence of cointegration, as determined by the presence of long-run Granger causality of $y_{i}$ to $y_{j}$, is measured by rejecting the null hypothesis $\left(H_{0}\right):$ " $\alpha_{j, h}=0$ ", where $b=1 \sim r$. The Existence of short-run Granger causality (jointly) of $y_{i}$ to $y_{j}$ can be identified by rejecting the null hypothesis $\left(H_{0}\right):$ " $\beta_{i j, 1}=\ldots \beta_{i j, p-1}=0$ ” using the Wald test, compared against chi-square distribution (Lutkepohl \& Kratzig 2004). The presence of Granger causality ( $y_{i}$ Granger cause $y_{j}$ ) can be finalized by rejecting at least one of the above two null hypotheses.

\section{Empirical Results}

The three step statistical analysis developed and utilized for this study generated empirical results. Table 2 shows results for unit root and stationary tests conducted using ADF and PP statistics. All five variables have unit root and are not stationary in level. But, each variable becomes stationary with no unit roots after first differencing. Then the null hypothesis can be rejected at 5\% significance level. This implies that all variables are integrated in the same order $\mathrm{I}(1)$. 
Table 2: Unit root test results

\begin{tabular}{lllll}
\hline \hline \multirow{2}{*}{ Variable } & \multicolumn{2}{c}{ ADF probability value } & \multicolumn{2}{c}{ PP probability value } \\
\cline { 2 - 5 } & level & $1^{\text {st }}$ difference & level & $1^{\text {st }}$ difference \\
\hline $\ln \mathrm{G}$ & 0.99 & $0.00^{*}$ & 0.99 & $0.00^{*}$ \\
$\ln \mathrm{NNV}$ & 0.14 & $0.00^{*}$ & 0.13 & $0.00^{*}$ \\
$\ln \mathrm{M} 2 \mathrm{G}$ & 0.66 & $0.00^{*}$ & 0.58 & $0.00^{*}$ \\
$\ln \mathrm{BD}$ & 0.82 & $0.00^{*}$ & 0.78 & $0.00^{*}$ \\
$\ln \mathrm{PDC}$ & 0.24 & $0.00^{*}$ & 0.22 & $0.00^{*}$ \\
\hline
\end{tabular}

* denotes rejection of null hypothesis of unit root

The next step was to test for cointegration among variables. Table 3 shows the optimal lag lengths $\left(p^{*}\right)$ revealed from both AIC and SC from the unrestricted VAR model, as used for the Johansen cointegration test and subsequently in the VECM.

Table 3: Selection of lag order

\begin{tabular}{|c|c|c|c|c|c|c|}
\hline \multirow[b]{2}{*}{$\begin{array}{ll}\text { Lag } & \text { order } \\
\text { (p) } & \end{array}$} & \multicolumn{2}{|c|}{ 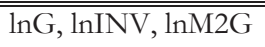 } & \multicolumn{2}{|c|}{$\bar{l} \ln G, \ln I N V, \ln B D$} & \multicolumn{2}{|c|}{ 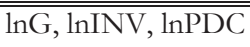 } \\
\hline & AIC & SC & AIC & SC & AIC & SC \\
\hline 0 & 0.82 & 0.94 & 1.05 & 1.17 & 3.57 & 3.69 \\
\hline 1 & -7.59 & -7.11 & -7.32 & -6.84 & $-4.68^{*}$ & $-4.20^{*}$ \\
\hline 2 & -8.12 & 7.14 & -7.61 & -6.77 & -4.52 & -3.68 \\
\hline 3 & $-8.35^{*}$ & $-7.28^{*}$ & $-8.06^{*}$ & $-6.86^{*}$ & -4.34 & -3.13 \\
\hline 4 & -8.27 & -6.70 & -7.90 & -6.33 & -4.09 & -2.53 \\
\hline
\end{tabular}

* Indicates the lag order selected by the criterion

Table 4 shows test results of Trace statistics and Maximum Eigenvalue statistics. Both tests support the identification of a long-run relationship between economic growth and financial development. 
Table 4: Johansen cointegration test results

\begin{tabular}{|c|c|c|c|c|}
\hline & & \multicolumn{3}{|l|}{ Variables } \\
\hline & & $\ln G, \ln I N V, \ln M 2 G$ & $\ln G, \ln I N V, \ln B D$ & $\ln G, \ln I N V, \ln P D C$ \\
\hline \multicolumn{2}{|l|}{$p^{*}$} & 3 & 3 & 1 \\
\hline \multirow{7}{*}{$\begin{array}{l}\text { Trace Statistics } \\
\text { (0.05 critical value) }\end{array}$} & $\mathrm{r}=0$ & 46.2 & 57.8 & 37.8 \\
\hline & & $(29.8)$ & $(42.9)$ & $(35.0)$ \\
\hline & $r=1$ & 19.5 & 25.7 & 15.9 \\
\hline & & $(15.5)$ & $(25.8)$ & $(18.4)$ \\
\hline & $r=2$ & 0.03 & 9.3 & 5.7 \\
\hline & & (3.8) & $(12.5)$ & (3.8) \\
\hline & $r^{*}$ & 2 & 1 & 1 \\
\hline \multirow{4}{*}{$\begin{array}{l}\text { Maximum Eigen } \\
\text { value statistics }\end{array}$} & $\mathrm{r}=0$ & 26.7 & 32.1 & 21.9 \\
\hline & & $(21.1)$ & $(25.8)$ & $(24.2)$ \\
\hline & $r=1$ & 19.4 & 16.4 & 10.2 \\
\hline & & $(14.2)$ & (19.4) & $(17.1)$ \\
\hline \multirow[t]{3}{*}{ (0.05 critical value) } & $r=2$ & 0.03 & 9.3 & 5.7 \\
\hline & & (3.8) & $(12.5)$ & $(3.8)$ \\
\hline & $r^{*}$ & 2 & 1 & 0 \\
\hline
\end{tabular}

$\overline{p^{*} \text { represents optimal lag length based on AIC and SC lag length criteria, } r \text { is the hypothesized number }}$ of cointegration, $r^{*}$ is the number of cointegrations obtained from the test results. Values in the bracket are 0.05 critical values.

When critical value is higher than the cointegration test value, we can accept the existence of the hypothesized number of cointegration. Interpretation of the $1^{\text {st }}$ model that used $\mathrm{M} 2 \mathrm{G}$ as proxy for the financial development: when $r=0$, Trace statistic value 46.2 is higher than the critical value 29.8 at $5 \%$ significance level. Hence, $r=0$ was rejected. Then considering $r=1$, again trace statistics value $>$ critical value $(19.5>15.5)$. Hence $r=1$ was rejected. However, considering $\mathrm{r}=2$, critical value $>$ trace statistics value $(3.8>0.03)$. Hence, $\mathrm{r}=2$ can be accepted as the number of cointegration obtained from the test results $\left(r^{*}=2\right)$ at $5 \%$ significance level.

Further, the $2^{\text {nd }}$ model that used BD as proxy for financial development: considering $r=1$, critical value $>$ trace statistics $(25.8>25.7)$. Hence $r=1$ can be accepted as the number of cointegration. Finally the $3^{\text {rd }}$ model that used PDC as the proxy for FD: $r=1$ [critical value $>$ trace value $(18.4>15.9)$ ] can be accepted as the number of cointegration. The $r^{*}$ for models using both cointegration tests could be obtained as explained above. 
Maximum Eigenvalue statistics show cointegration for two cases, M2G and BD, used in the models as the financial development indicator, but not in the case of PDC. However, as per the results of Trace statistics, all cases show at least one cointegration and the null hypothesis of no-cointegration can be rejected 5\% significance level.

Based on the results of cointegration tests, VECM was performed to determine the long-run and short-run Granger causality and relevant direction.

Table 5: Results of Granger causality test (long-run analysis)

\begin{tabular}{|c|c|c|c|}
\hline FD indicators & $r^{*}$ & $\begin{array}{c}\text { Null Hypothesis }{ }^{\mathrm{a}} \mathrm{t}\left(\alpha_{1}=0\right) \\
\mathrm{t}\left(\alpha_{1}\right)\end{array}$ & $\alpha_{1}$ \\
\hline $\ln M 2 G$ & 2 & $\begin{array}{r}0.57 \\
-0.36\end{array}$ & $\begin{array}{r}0.00 \\
-0.04\end{array}$ \\
\hline $\begin{array}{c}\ln B D \\
\ln P D C\end{array}$ & $\begin{array}{l}1 \\
1\end{array}$ & $\begin{array}{l}-2.21 * \\
-2.92^{*}\end{array}$ & $\begin{array}{l}-0.22 \\
-0.22\end{array}$ \\
\hline & & $\begin{array}{l}\text { Null Hypothesis }{ }^{\mathrm{b}} \mathrm{t}\left(\alpha_{2}=0\right) \\
\mathrm{t}\left(\alpha_{2}\right)\end{array}$ & $\alpha_{2}$ \\
\hline $\ln M 2 G$ & 2 & $\begin{array}{l}2.60 \\
0.49\end{array}$ & $\begin{array}{l}0.02 \\
0.07\end{array}$ \\
\hline $\begin{array}{c}\ln B D \\
\ln P D C\end{array}$ & $\begin{array}{l}1 \\
1\end{array}$ & $\begin{array}{r}1.64 \\
-1.48\end{array}$ & $\begin{array}{r}0.22 \\
-0.52\end{array}$ \\
\hline & & $\begin{array}{c}\text { Null Hypothesis }{ }^{\mathrm{c}} \mathrm{t}\left(\alpha_{3}=0\right) \\
\mathrm{t}\left(\alpha_{3}\right)\end{array}$ & $\alpha_{3}$ \\
\hline $\ln M 2 G$ & 2 & $\begin{array}{c}1.12 \\
-4.30^{*}\end{array}$ & $\begin{array}{c}0.01 \\
-0.84\end{array}$ \\
\hline $\begin{array}{l}\ln \mathrm{BD} \\
\ln \mathrm{PDC}\end{array}$ & $\begin{array}{l}1 \\
1\end{array}$ & $\begin{array}{l}5.01 \\
2.36\end{array}$ & $\begin{array}{l}0.85 \\
0.43\end{array}$ \\
\hline
\end{tabular}

$\mathrm{t}\left(\alpha_{1}=0\right)$ the t-statistic testing the null hypothesis, which is $\alpha_{i}=0$ in equations (3) - (5), (where $\left.\mathrm{i}=y_{1}, y_{2}, y_{3}\right)$.

* Presence of long-run relationship (negative ECT is significant at 5\% level).

${ }^{a}$ Financial Development $\left(y_{2}\right)$ does not Granger cause economic growth $\left(y_{1}\right)$.

b Economic growth (direct or indirect) $\left(y_{1}, y_{3}\right)$ does not Granger cause financial development $\left(y_{2}\right)$.

c Financial Development $\left(y_{2}\right)$ does not Granger cause economic growth (indirect) $\left(y_{3}\right)$.

In the VECM, Table 5 shows results that explain the long-run relationship. In the model, the null hypothesis is non-existing of long-run causality $\left(H_{0}\right)$ : " $\alpha_{i}=0$ ". In the VECM [three equations i.e. (3) - (5)], $y_{2}$ represents three financial indicators (M2G, BD, PDC) and shows $3 \times 3$ time of results of $\mathrm{t}$ statistics for the $\alpha_{i}$ (error correction coefficient). Results based on equation 3 revealed that long-run causality of financial development to economic growth can 
be observed when financial development is measured by either BD or PDC. Hence, we can reject the null hypothesis of $\alpha_{1}=0$, at 5\% significance level [- $\mathrm{t}\left(\alpha_{1}\right)>1.96$ ].

Further, results of VECM (equation 5) shows long-run Granger causality from M2B to INV, meaning that there is indirect causality of financial development to economic growth. Thus, the null hypothesis of $\alpha_{3}=0$ can be rejected at 5\% significance level. This result helps to maintain the robustness of the VECM.

In summary, the model has a strong one directional long-run causality from financial development (with all financial indicators) to economic growth. This means shocks made in the short-run can adjust towards equilibrium in the long-run. These results are in line with the supply leading hypothesis, and the long-run Sri Lankan economy behaves as per Schumpeter's assumption.

Table 6: Results of Granger causality test (short-run analysis)

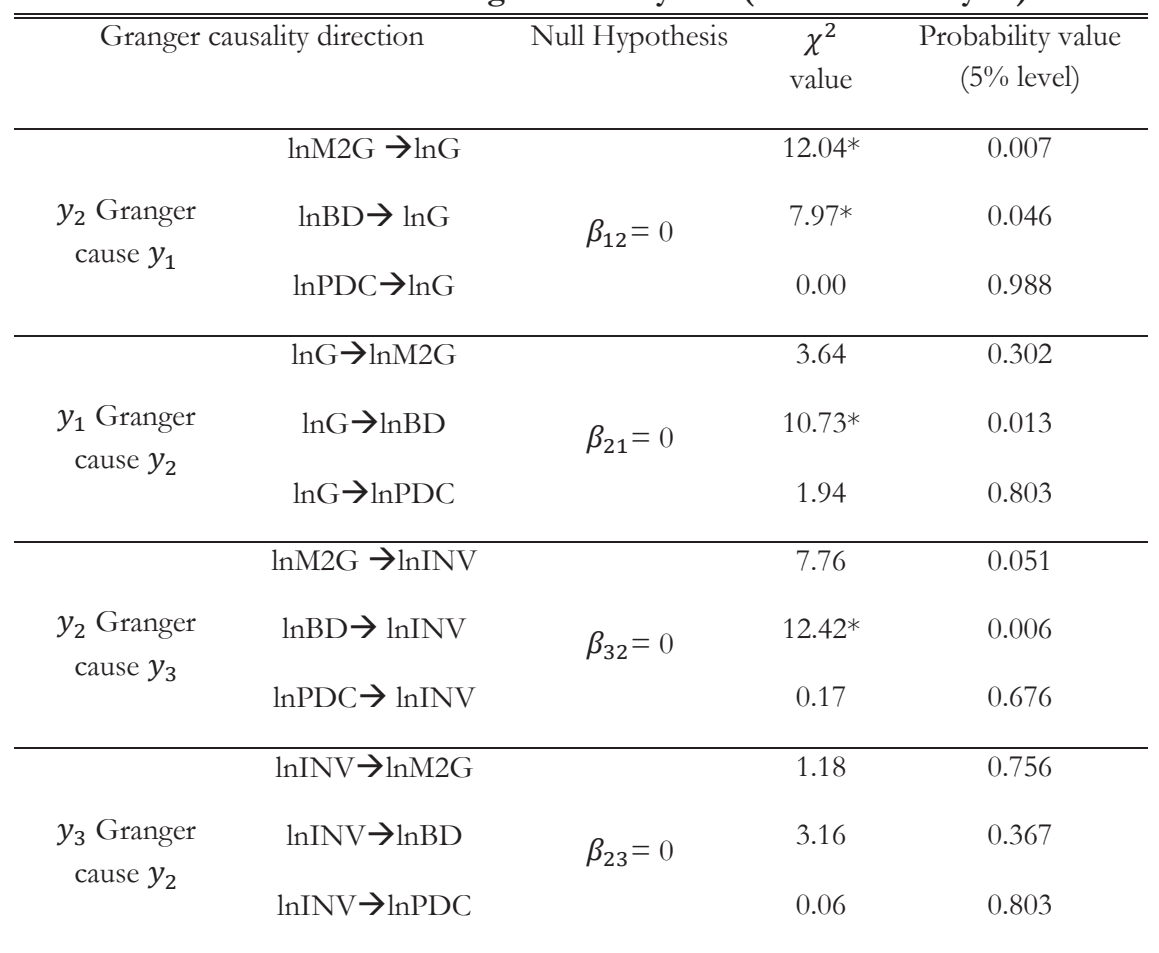

* Presence of short-run Granger causality

Short-run Granger causality between financial development and economic growth can be tested by using the Wald test (results in Table 6). The null hypothesis of the model is the nonexistence of short-run causality $\left(H_{0}\right): " \beta_{i j}=0$ ". When BD was used as the proxy to measure 
the degree of financial development, results show bi-directional short-run Granger causality between BD and G. Further, another causality relationship was detected from BD to INV. Also, M2G as a measurement variable of financial development presence, short run causality from $\mathrm{M} 2 \mathrm{G}$ to $\mathrm{G}$, but PDC did not show significant relationships. Finally, results reveal that the null hypotheses $\left(H_{0}\right): " \beta_{12}=\beta_{21}=\beta_{32}=0$ " can be rejected at $5 \%$ significance level with the existence of short-run Granger causality between financial development and economic growth. Hence, in the short-run BD shows the reciprocal hypothesis and M2G shows the supply leading hypothesis.

In summary, development of the financial sector and economic growth in Sri Lanka has existed as a long-run relationship over the last five decades. By including investment as a proxy for economic growth measurement, results show that all variables measuring financial development indicate long-run causality with economic growth. The model that used BD to represent financial development resulted in strong bidirectional short-run causality, whereas M2G Granger cause to economic growth was uni-directional. The empirical results of this study are compared to empirical results found in the literature in the following section.

\section{Discussion of Study Results and Empirical Literature}

Arestis and Demetriades (1996) explain that causality directions of financial development and economic growth may depend on the measurement variables used, and policies and institutional behaviors of the particular country.

A study based on OECD countries, shows a strong relationship between financial development and growth in the initial phase of the development process, which shrinks as the country develops (Goldsmith 1969). Odeniran and Udeaja (2010) explain that the financial revolution was boosted by industrialization, as demonstrated by an analysis of the US and Japan before World War I. Furthermore, Abubaker and Gani (2013) state that the resolution of institutional and structural matters in the economies of underdeveloped countries requires focus on strong domestic financial intermediaries.

Shin (2013) identifies four types of economy, based on four legal frameworks: English, German, French and Scandinavian law. Considering law as an instrumental variable, it was found that the degree to which the financial sector developed correlated strongly with the application of commercial or company law, which subsequently caused growth of the economy (Shin 2013).

Hence, the above studies show that the causal relationship between financial development and growth can vary as a result of several conditions, such as the level of development and legal framework. There are several empirical theories regarding the causal relationship between different kinds of economic measurement variables. Apart from identifying the nexus between 
finance and growth, selecting the indicators that determine financial development is a major task, as different indicators produce different results for different countries' economies.

The results of this study show that Sri Lanka's economy follows the supply leading hypothesis where all measurements of financial development, including domestic credit to the private sector, money supply and bank deposits, indicate a long-run relationship with growth. This finding was also reported by Odenarian and Udeaja (2010) in their study of the Nigerian economy. Furthermore, Perera and Paudel (2009) also found that domestic private credit had a causal effect in Sri Lanka, and recently, Alkhuzaim (2014) confirmed that domestic credit impacts GDP in the long-run in the economy of Qatar. However, Amarathunga (2010) concludes that the Sri Lankan economy shows only demand following hypothesis, where trade is taken as a financial development measurement and investment as the growth indicator.

Short-run Granger causality results of this study shows the supply leading hypothesis, where money supply is used as a financial development indicator. This result is in line with the findings of Kar \& Pentecost (2000) in the Turkish economy, when the same proxy is used as a financial development indicator. However, for the same economy, these authors found that by using bank deposits and private domestic credit proxies as financial development measures, growth drives economic development. This finding is in line with Robinson's (1952) demand following hypothesis. Alkhuzaim (2014) argued for the same causality for growth to drive financial development in the short-run. Similarly, Perera and Paudel (2009) reported a unidirectional demand following causality hypothesis with economic growth, when narrow money, total domestic credit and private sector credit are used as financial development indicators. According to the results of this study, Sri Lanka's economy is not in line with the unique demand following hypothesis.

Some economic systems exhibit the causality of reciprocal hypothesis when mixes of indicators are used for financial sector development. In this study, the reciprocal causality hypothesis was identified in the short-run when bank deposits were used to represent financial development. Some economies show the same reciprocity with bidirectional causality between financial development and economic growth for both private domestic credit and total domestic credit. In line with the above conclusions, Perera and Paudel (2009) and Alkhuzaim (2014) found bi-directional causality with money supply and economic growth. Furthermore, using Egyptian data Abu-Bader and Abu-Qarn (2007) show all measurements for financial development, private domestic credit, ratio of private credit to total domestic credit, money supply and bank deposits, exhibit long-run bi-directional causality with growth. Similar to this study, these authors used investment as the second variable to measure economic growth, to achieve robustness of causality behavior.

In contrast to the above empirical findings, Acaravci et al (2007) found no evidence for longrun causality between financial development and economic growth. Furthermore, Alkhuzaim (2014) confirmed this neutrality hypothesis by using domestic private credit as a financial 
sector indicator. Results of this study show same neutrality hypothesis in short-run when domestic private credit used as the proxy for financial development.

\section{Conclusion and Policy Implications}

The aim of this study was to determine the causality behavior between development of financial intermediaries and the economic growth in Sri Lanka for the past four and a half decades. This study employs Granger causality tests under the environment of cointegration and VECM.

Results revealed that financial development causes economic growth in the long-run in Sri Lanka, using the financial measures of money supply, bank deposits and private domestic credit. This evidence of a long-run causal relationship was supported by investment/GDP, which was taken as a proxy for measuring indirect economic growth. Further, these results suggest evidence of bi-directional short-run causalities between bank deposits and growth, and unidirectional causality from money supply to growth. Since financial intermediary indicators represent dynamic causality with economic growth, policy makers should actively develop policies to maintain sustainability of economic growth.

The role of the Central Bank in long run financial development: Keep the soundness of the financial system under both favorable and less favorable economic environments, influence the indicators of financial deepening through branch banking and ATM penetration, avoid the substantial disparities across the population of individuals and firms in the economy. i.e., allow poor and rural population comfortable access to finance, promote financial inclusion and regional integration, which will create a big, broad, deep, enough liquid and efficient financial market. It is also important to minimize the information gap between micro-prudential nature and macro prudential analysis which can arise from macroeconomic or financial development.

Policies should aim to enhance financial development through the consolidation of the financial-real sector long-run relationship, augmenting credit market competition, relaxing the legal environment to promote new investors and entrepreneurs, and ensuring a tough legal environment to discourage corruption. These measures will develop a better saver-investor relationship to improve the productivity of Sri Lanka. 


\section{References}

Abu-Bader, S., Abu-Qarn, A.S., 2008. Financial development and economic growth: The Egyptian experience. Journal of Policy Modeling 30, 887-898.

Abubakar, A., Gani, I.M., 2013. Impact of Banking Sector Development on Economic Growth: Another Look at the Evidence from Nigeria. Journal of Business Management \& Social Sciences Research 2, 47-57.

Acaravci, A., Ozturk, I., Acaravci, S.K., 2007. Finance - Growth Nexus: Evidence from Turkey. International Research Journal of Finance and Economics 11, 30-40.

Alkhuzaim, W., 2014. Degree of Financial Development and Economic Growth in Qatar: Cointegration and Causality Analysis. International Journal of Economics and Finance 6, 5769.

Amarathunga, H., 2010. Staff Studies, Central Bank of Sri Lanka, 40 Volume 40 Numbers 1 $\& 2,2010$

Arestis, P., Demetriades, P., 1997. Financial Development and Economic Growth: Assessing the Evidence. The Economic Journal 107.

Blum, D., Federmair, K., Fink, G., Haiss, P., 2002. The Financial-Real Sector Nexus: Theory and Empirical Evidence Research Institute for European Affairs. University of Economics and Business Administration-Vienna 43.

Bojanic, A.N., 2012. The Impact of Financial Development and Trade on the economic Growth of Bolivia.Journal of Applied Economics 15, 51-70.

Central Bank of Sri Lanka (CBSL), 1978. Annual Report.

Central Bank of Sri Lanka (CBSL), 2001. Annual Report.

Central Bank of Sri Lanka (CBSL), 2013. Annual Report.

Central Bank of Sri Lanka (CBSL), 2014. Monetary-Policy-Review-September

Enders, W., 2009. Applied Econometric Time Series (3rd Edition), John Wiley and Sons Ltd

Engle, R.F., Granger, C.W.J., 1987. Co-integration and Error Correction: Representation, Estimation, and Testing. Econometrica 55, 251.

Goldsmith, R.W., 1969. Financial Structure and Development. New Haven: Yale University Press.

Greenwood, J., Smith, B.D., 1997. Financial markets in development, and the development of financial markets. Journal of Economic Dynamics and Control 21, 145-181.

Johansen, S., 1988. Statistical analysis of cointegration vectors. Journal of Economic Dynamics and Control 12, 231-254.

Johansen, S., Juselius, K., 1990. Maximum Likelihood Estimation and Inference on Cointegration--With Applications to the Demand for Money. Oxford Bulletin of Economics and Statistics 52, 169-210. 
Levine, R., 1997. Financial Development and Economic Growth: Views and Agenda. Journal of Economic Literature. American Economic Association 35, 688-726.

Levine, R., 2005. Finance and Growth: Theory and Evidence. Department of Economics, Brown University.

Lutkepohl, H., Markus, K., 2004. Applied Time Series Econometrics. Cambridge University press.

Méon, P.-G., Weill, L., 2010. Does financial intermediation matter for macroeconomic performance? Economic Modelling 27, 296-303.

Muhsin, K., Pentecost, E.J., 2000. Financial Development and Economic Growth in Turkey. Further Evidence on the Causality Issue, Department of Economics, Loughborough University, Loughborough.

Odeniran, S.O., Udeaja, E.A., 2010. Financial Sector Development and Economic Growth: Empirical Evidence from Nigeria. Economic and Financial Review-Central Bank of Nigeria 48, 91-124.

Perera, N., Paudel, R.C., 2009. Financial development and economic growth in Sri Lanka. Applied Econometrics and International Development 9, 157-164.

Rajan, R.G., Zingales, L., 1998. Financial Dependence and Growth. The American Economic Review 88, 559-586.

Schumpeter, J. A., 1911. The theory of economic development, Cambridge, MA: Harvard University Press

Shaw, E.S., 1973. Financial deepening in economic development, New York: Oxford University Press.

Shin, Y., 2013. Financial Markets: An Engine for Economic Growth. The Regional Economists. The Federal Reserve Bank of St.Louis 21, 4-9.

Singh, T., 2008. Financial development and economic growth nexus: a time-series evidence from India. Applied Economics 40, 1615-1627.

Solow, R.M., 1956. A Contribution to the Theory of Economic Growth. The Quarterly Journal of Economics 70, 65-94.

Williamson, S.D., 2011. Macroeconomics. Pearson education.

World Bank, 2004. Sri Lanka Development Policy Review. Poverty Reduction and Economic Management Sector Unit, South Asia Region.

World development Indicators, (http://data.worldbank.org/data-catalog/worlddevelopment-indicators).

Wolde-Rufael, Y., 2009. Re-examining the financial development and economic growth nexus in Kenya. Economic Modelling 26, 1140-1146. 